\title{
LONCHIPHYLLUM APLOSPERMUM GEN. ET SP. NOV.: AN ANATOMICALLY PRESERVED GLOSSOPTERID MEGASPOROPHYLL FROM THE UPPER PERMIAN OF SKAAR RIDGE, TRANSANTARCTIC MOUNTAINS, ANTARCTICA
}

\author{
Patricia E. Ryberg ${ }^{1, *}$ and Edith L. Taylor* \\ *Department of Ecology and Evolutionary Biology and Natural History Museum and \\ Biodiversity Institute, University of Kansas, Lawrence, Kansas 66045, U.S.A.
}

\begin{abstract}
A new anatomically preserved megasporophyll, Lonchiphyllum aplospermum, is described from permineralized peat collected on Skaar Ridge in the central Transantarctic Mountains. This new genus contains vascular features similar to those of the leaf genus Glossopteris schopfii, which is the exclusive leaf genus in the specimens in which the sporophylls were found. The vasculature of the sporophyll consists of a central vascular region with bordered pitting and anastomosing lateral bundles with helical-scalariform thickenings. Ovules are attached oppositely to suboppositely to lateral veins on the adaxial surface of the sporophyll. There is an abundance of bisaccate pollen of the Protohaploxypinus type at the base of the ovules. The ovules of Lonchiphyllum are small $(1.1 \mathrm{~mm} \times 0.97 \mathrm{~mm})$ and ovate and have an unornamented integument. Comparison with anatomically known ovules from Skaar Ridge, i.e., Plectilospermum elliotii, Choanostoma verruculosum, and Lakkosia kerasata and Homevaleia gouldii from the Bowen Basin of Australia, supports the classification of Lonchiphyllum as a glossopterid. The differences in the sarcotesta and sclerotesta of all the Skaar Ridge ovules may indicate specialization for pollination or dispersal.
\end{abstract}

Keywords: Glossopteridales, glossopterids, ovules, megasporophylls, Permian, Antarctica.

\section{Introduction}

The Glossopteridales (pteridosperms) are found in Permian terrestrial strata across the Southern Hemisphere, with the majority of occurrences consisting of compression/impression fossils. Only a few areas have yielded anatomically preserved plant material to date. Permineralized peat from the Sydney and Bowen Basins in Queensland, Australia, has revealed glossopterid anatomy (leaves, stems, roots, sporophylls; Gould and Delevoryas 1977; Pigg and McLoughlin 1997; Nishida et al. 2004, 2007) as well as fossils assigned to Paleosmunda (Gould and Delevoryas 1977). In Antarctica, anatomical fossils are known from the Prince Charles Mountains in East Antarctica (McLoughlin and Drinnan 1996; Lindström et al. 1997) and Skaar Ridge in the central Transantarctic Mountains of Antarctica. This locality has also increased our knowledge of the anatomy of the glossopterids (leaves, stems, numerous ovules, megasporophylls, and a microsporophyll; Taylor and Taylor 1987; Pigg 1990; Pigg and Taylor 1993; Klavins et al. 2001; Ryberg 2010; Ryberg et al. 2012a). In addition to the glossopterids, a fern (Skaaripteris minuta), a moss (Merceria augustica), and a lycopsid (Collinsonostrobus eggertii) have been described from this locality (Smoot and Taylor 1986; Galtier and Taylor 1994; Ryberg et al. 2012b).

In Antarctica, permineralized material from the Skaar Ridge locality has uncovered a diversity of glossopterid reproductive structures. While several genera are known from

${ }^{1}$ Author for correspondence; e-mail: patricia.ryberg@park.edu.
Late Permian Antarctic impression specimens (Ryberg 2009), to date, three ovulate genera are known from permineralized fossils at Skaar Ridge (Taylor and Taylor 1987; Klavins et al. 2001; Ryberg 2010), one of which is attached to a sporophyll (Ryberg 2010). Microsporophylls arranged into a cone have also been described, and these may provide clues to the arrangement of megasporophylls on the plant (Ryberg et al. $2012 a$ ). The vegetative material present in the peat also provides evidence of how individual organs of a glossopterid plant were attached to each other. The discovery of Glossopteris leaves attached to shoots (Pigg and Taylor 1993) and ovules attached to a megasporophyll (Ryberg 2010) contributes to a more complete reconstruction of a glossopterid plant.

This article presents detailed anatomy of a second sporophyll from the Skaar Ridge peat. The ovules attached to this sporophyll indicate the presence of at least four potential glossopterid plants at this locality. In addition to this new sporophyll, a brief review of previously described ovules is also presented for a comparison of anatomy, morphology, potential pollination mechanisms, and dispersal methods.

\section{Material and Methods}

Specimens were collected from the Skaar Ridge locality of the Queen Alexandra Range at the head of the Beardmore Glacier (lat. $84^{\circ} 49^{\prime} 11.8^{\prime \prime} \mathrm{S}$, long. $163^{\circ} 20^{\prime} 37^{\prime \prime} \mathrm{E}$ ) during the 1985 and 2003 austral field seasons. Material came from near the top of the ridge in silicified peat dominated by the root genus Vertebraria. Skaar Ridge deposits have been dated as late Permian on the basis of palynomorphs (Farabee et al. 1991) 
and are within the upper Buckley Formation (Barrett et al. 1986; for additional locality information, see Ryberg 2010).

Specimens were cut into slabs with a lapidary saw and then immersed in hydrofluoric acid (49\%) to dissolve the silica. Acetate peels were produced from the etched surfaces using the acetate peel technique (Joy et al. 1956) modified for hydrofluoric acid (Galtier and Phillips 1999). Peels were mounted on microscope slides with Eukitt mounting medium (O. Kindler, Freiburg, Germany). Digital images were obtained on a Leica 5000C compound microscope and processed in Photoshop CS4. Measurements of specimens were carried out in ImageJ (Rasband 1997-2008). All specimens, peels, slides, and digital images are housed in the University of Kansas Natural History Museum, Division of Paleobotany (KUPB), under acquisition numbers KUPB 10,045 and 15,509 and slide acquisition numbers $26,610-26,739$.

\section{Geologic Setting}

Late Permian deposits of the central Transantarctic Mountains of Antarctica have been reconstructed as a low-gradient floodplain crossed by a braided river system (Isbell 1991). Local stratigraphic and sedimentologic analysis has not been carried out at Skaar Ridge, but contemporaneous deposits of in situ forests in the Beardmore Glacier region reveal fossils preserved in low-energy environments such as floodplains, channel margins, abandoned channels/backswamps, and lake margins (Gulbranson et al. 2012). The abundance of permineralized leaf mats at Skaar Ridge suggests that they were deposited in a lake margin or an abandoned channel because the fine detail preserved in the fossils indicates that the peat was not transported far before fossilization. Silica for the preservation process was provided from volcanic material moving downstream from the head of the foreland basin (Collinson 1991).

\section{Results}

\section{Systematic Description}

\section{Class_-Glossopteridopsida Banerjee 1984}

Order-Glossopteridales Banerjee 1984

Genus-Lonchiphyllum gen. nov. (Figs. 1-4)

Derivation of generic name. Derived from the Greek term "lonchi," in reference to the probable spear shape of the
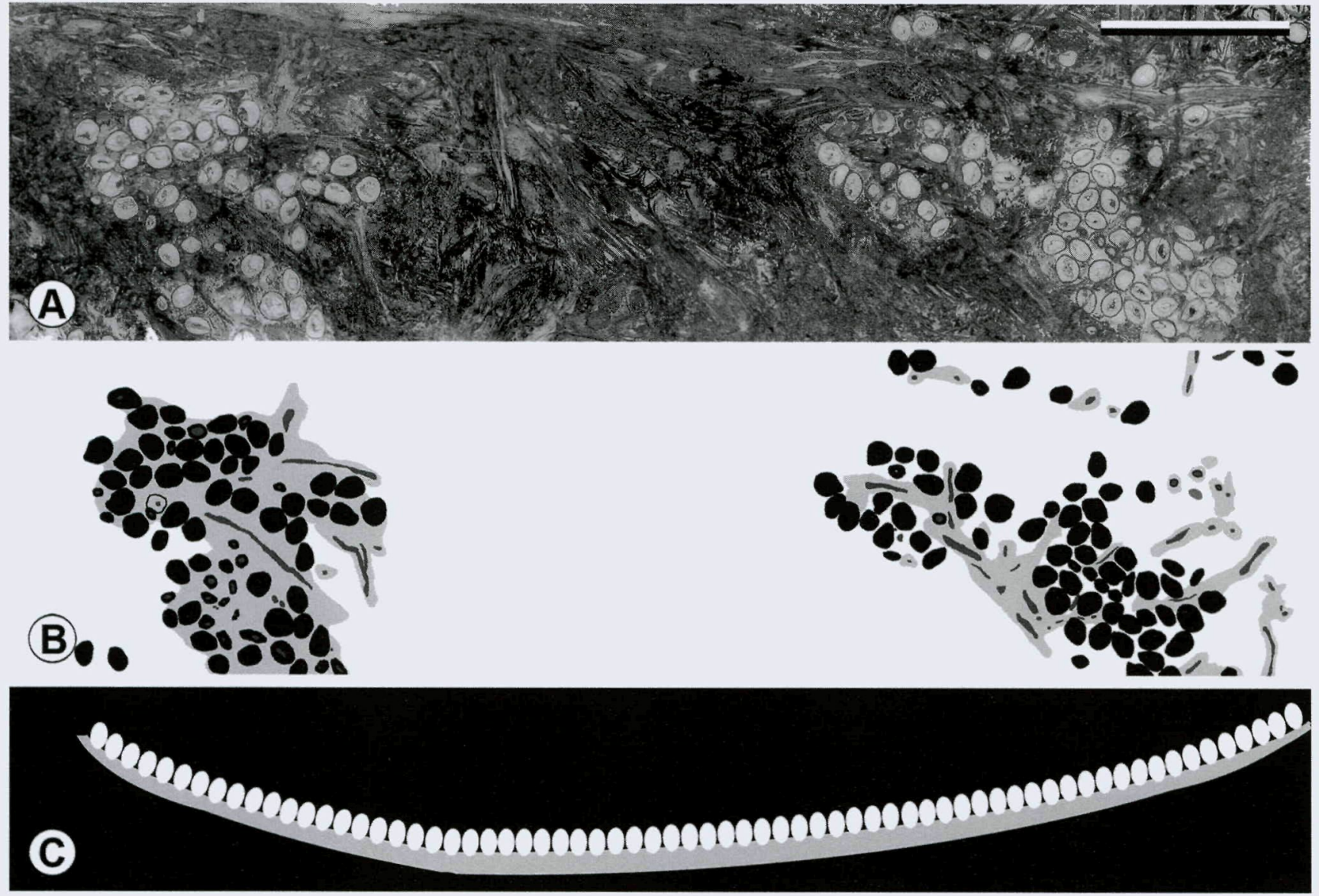

Fig. 1 Lonchiphyllum aplospermum holotype 15509 Cbot. A, Oblique paradermal section of a megasporophyll with numerous ovules attached. KU slide acquisition 26,679 (scale bar $=1 \mathrm{~cm}$ ). $B$, Line drawing of $A$. Black = ovules; light gray = mesophyll tissue; dark gray = vascular tissue. $C$, Line drawing of a medial longitudinal section of the holotype and its orientation in the rock. Notice that ovules on the right side are closer to the surface than those on the left, which are closer to the surface than ovules in the center. 


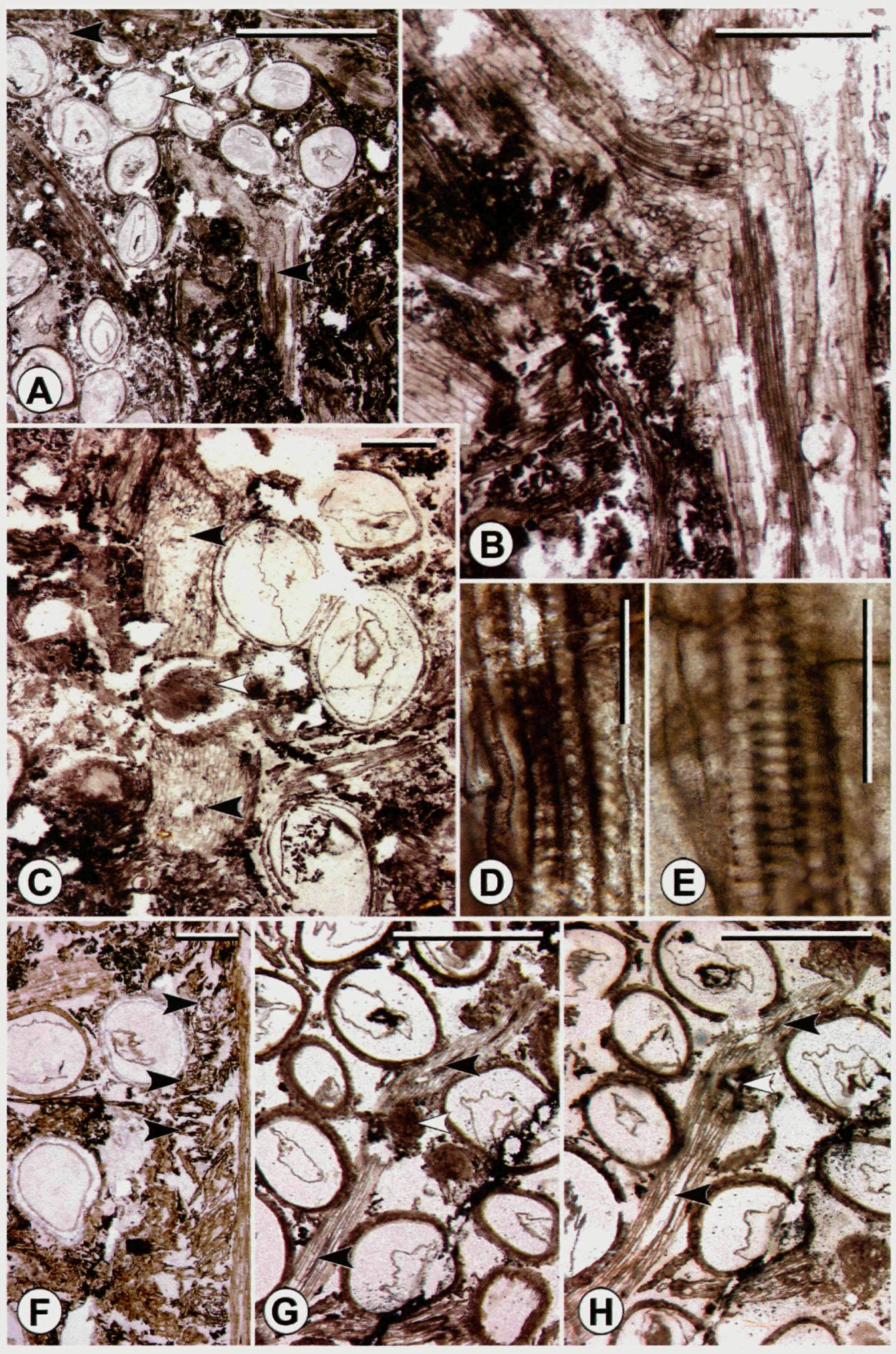

Fig. 2 Lonchiphyllum aplospermum holotype 15509 Cbot. A, Oblique paradermal section of a midrib in the megasporophyll with a branching lateral vein (black arrowheads) and attached ovule (white arrowhead); cells surrounding veins are mesophyll cells. KU slide acquisition 26,661 (scale bar $=1 \mathrm{~mm}, 50 \times \mathrm{mag}$ ). $B$, Higher magnification of $A$, with a lateral vein diverging from the midrib. KU slide acquisition 26,661 (scale bar $=$ $0.5 \mathrm{~mm}, 80 \times \mathrm{mag})$. C, Oblique paradermal section showing an ovule (white arrowhead) attached on a subtending lateral vein (black arrowheads). KU slide acquisition 26,672 (scale bar $=0.5 \mathrm{~mm}, 63 \times \mathrm{mag}$ ). $D$, Longitudinal section of the midrib illustrating circular bordered pitting on tracheid walls. KU slide acquisition 26,662 (scale bar $=0.05 \mathrm{~mm}, 630 \times \mathrm{mag}$ ). $E$, Longitudinal section of a lateral vein with scalariform thickenings in the 
ovulate structure, and the Greek term "phyllum," for the leaf-like morphology of the reproductive structure.

Generic diagnosis. Laminar megasporophyll with midrib and anastomosing venation. Mesophyll parenchymatous and uniform; vasculature with helical, scalariform, and circular bordered pitting, prominent phloem lacunae and bundle sheaths; adaxially attached orthotropous ovules opposite to subopposite on lateral veins, slightly sunken into sporophyll, wingless with trilayered integument.

\section{Type Species_Lonchiphyllum aplospermum sp. nov.}

Derivation of specific name. Derived from the Greek "aplos," which is translated to "simple," in reference to the simple nature of the integument and lack of ornamentation of the ovule, and the Greek "spermum" for "seed," indicating that these are seeds.

Specific diagnosis. Megasporophyll mesophyll parenchymatous $0.1 \mathrm{~mm} \times 0.4 \mathrm{~mm}$. Small orthotropous ovules $1.1 \mathrm{~mm} \times$ $0.97 \mathrm{~mm}$, attached to lateral veins by short vascularized stalks. Ovules ovate with a three-layered integument; inner layer fibrous, 2-3 cells thick; middle layer of heavily sclerified cells, 2-3 cells thick; outer layer of large cells with exterior thickenings. Surface of ovules smooth with a simple micropyle.

Holotype. KUPB 15,509 C-bot (figs. 1-4).

Paratype. KUPB 10,049 L-bot.

Type locality. Skaar Ridge, Queen Alexandra Range, central Transantarctic Mountains, Antarctica.

Stratigraphy. Upper Permian, upper Buckley Formation, Beacon Supergroup.

Repository. All material, including specimens, peels, and slides, is housed in KUPB, Lawrence, Kansas.

\section{Description and Interpretation}

Sporophyll. At least two sporophylls are present, but their occurrence in leaf mats and bioturbation by Vertebraria roots prevent determining the total number of sporophylls that may be present and all the morphological features of the genus. All specimens are in paradermal section, with the majority of the ovules in cross section. The region containing ovules measures $4.6 \mathrm{~cm} \times 0.9 \mathrm{~cm}$ overall, suggesting that the sporophyll was lanceolate in shape and similar to the glossopterid impression genus Dictyopteridium (fig. 1). More than 150 ovules are attached to the adaxial side of the sporophyll. Ovules are slightly sunken into the surface of the sporophyll.

The presence of a midrib with numerous veins is not easily identifiable, but the presence of regions with circular bordered pitting (fig. $2 A, 2 B, 2 D$ ) in the vasculature and an absence of attached ovules suggest the presence of a midrib (fig. $2 A, 2 B)$. Additional support for a midrib is the presence of lateral veins with attached ovules branching off the region with helical to scalariform pitting (fig. $2 A, 2 B, 2 E$ ). Approximately 15 tracheids are present in the vasculature of the midrib and around five tracheids in lateral veins. Ovules are oppositely to suboppositely attached in two rows adaxial to a vein (fig. $2 \mathrm{G}, 2 \mathrm{H}$ ). Sectioning paradermally from the ovules into the sporophyll reveals the base of ovules, followed by xylem, next a phloem lacuna, and, finally, mesophyll cells (fig. $2 \mathrm{G}, 2 \mathrm{H}$ ). A small bundle of tracheids runs from the lateral veins into the base of the ovule and appears to terminate in the chalazal end of the ovule. The presence of a circular bundle sheath and phloem lacuna as well as the structure of the anastomoses in the sporophyll suggests affiliation with the leaf Glossopteris schopfii (fig. 2F; Pigg 1990) because these are distinctive features of this species. In addition to this, the leaves in the peat that contains the sporophylls are exclusively G. schopfii.

Mesophyll tissue is not generally preserved except around the veins (fig. $2 A-2 C, 2 G, 2 H$ ), and this, in addition to the presence of numerous veins from vegetative leaves that surround the mesophyll, prevents definitive measurement of the size and shape of the sporophyll. Preserved mesophyll cells are rectangular and measure $0.04-0.1 \mathrm{~mm} \times 0.02-0.04 \mathrm{~mm}$ (fig. 2A, 2B). Thickenings on the walls were not observed.

Ovules. The majority of the ovules are cut in transverse section, but a few are in longitudinal section. Several appear to be detached from the sporophyll, on the basis of their orientation, but have remained near their original position. Ovules are ovate and bilaterally symmetrical, measuring $1.1 \mathrm{~mm} \times 0.97 \mathrm{~mm}$ (fig. $3 A$ ). All ovules are unwinged. Cells on either side of the micropyle are appressed to each other, sealing off the interior of the ovule, indicating that perhaps pollination has already occurred (fig. $3 B$ ). There is little modification of the sclerotesta near the micropyle, only a few cells that are larger than the rest of the cells in the layer. Little to no ornamentation is evident on the ovules. In most of the ovules, cells of the integument are not preserved.

Sarcotesta. The sarcotesta is a single cell layer wide and is composed of large rectangular cells measuring $19 \mu \mathrm{m} \times$ $12 \mu \mathrm{m}$ in longitudinal section (fig. $3 \mathrm{C}$ ). The walls of the cells are thick $(5 \mu \mathrm{m})$, with the exterior and anticlinal walls much thicker than the interior wall. The thicker exterior wall may also indicate the presence of a thick cuticle on the ovule. There is no ornamentation of the sarcotesta, and wings are not formed. At the micropylar end of the ovule, the sarcotesta is not readily observed because the sclerotestal cells are large and dominate this region.

Sclerotesta. The sclerotesta is $\sim 20 \mu \mathrm{m}$ thick and up to 10 cells across. All of the cells are uniform in type, with heavily sclerified walls. Longitudinally, the cells appear isodiametric and measure $5 \mu \mathrm{m}$ in diameter, with a wall thickness of $\sim 2 \mu \mathrm{m}$ (fig. $3 \mathrm{C}$ ). At the micropylar end of the ovule, the thickness of the integument more than doubles $(80 \mu \mathrm{m})$ as

tracheids. KU slide acquisition 26,662 (scale bar $=0.05 \mathrm{~mm}, 630 \times \mathrm{mag}$ ). $F$, Oblique transverse sections of ovules and circular vascular bundles with phloem lacunae (black arrowheads). KU slide acquisition 26,656 (scale bar $=0.5 \mathrm{~mm}, 63 \times \mathrm{mag}$ ). G, Oblique paradermal section of a sporophyll with oppositely attached ovules on a vein. The chalazal end of one ovule (white arrowhead) is attached to the vein; black arrowheads point to xylem tracheids. KU slide acquisition 26,662 (scale bar $=1 \mathrm{~mm}, 50 \times \mathrm{mag}$ ). $H$, Oblique paradermal section of a sporophyll directly basal to the one in $G$. Black arrowheads point to phloem lacunae in the same positions as the xylem in $G$, illustrating that the ovules are attached to the adaxial surface of the sporophyll. White arrowhead points to the same ovule as in C. KU slide acquisition 26,663 (scale bar $=1 \mathrm{~mm}, 50 \times \mathrm{mag}$ ). 

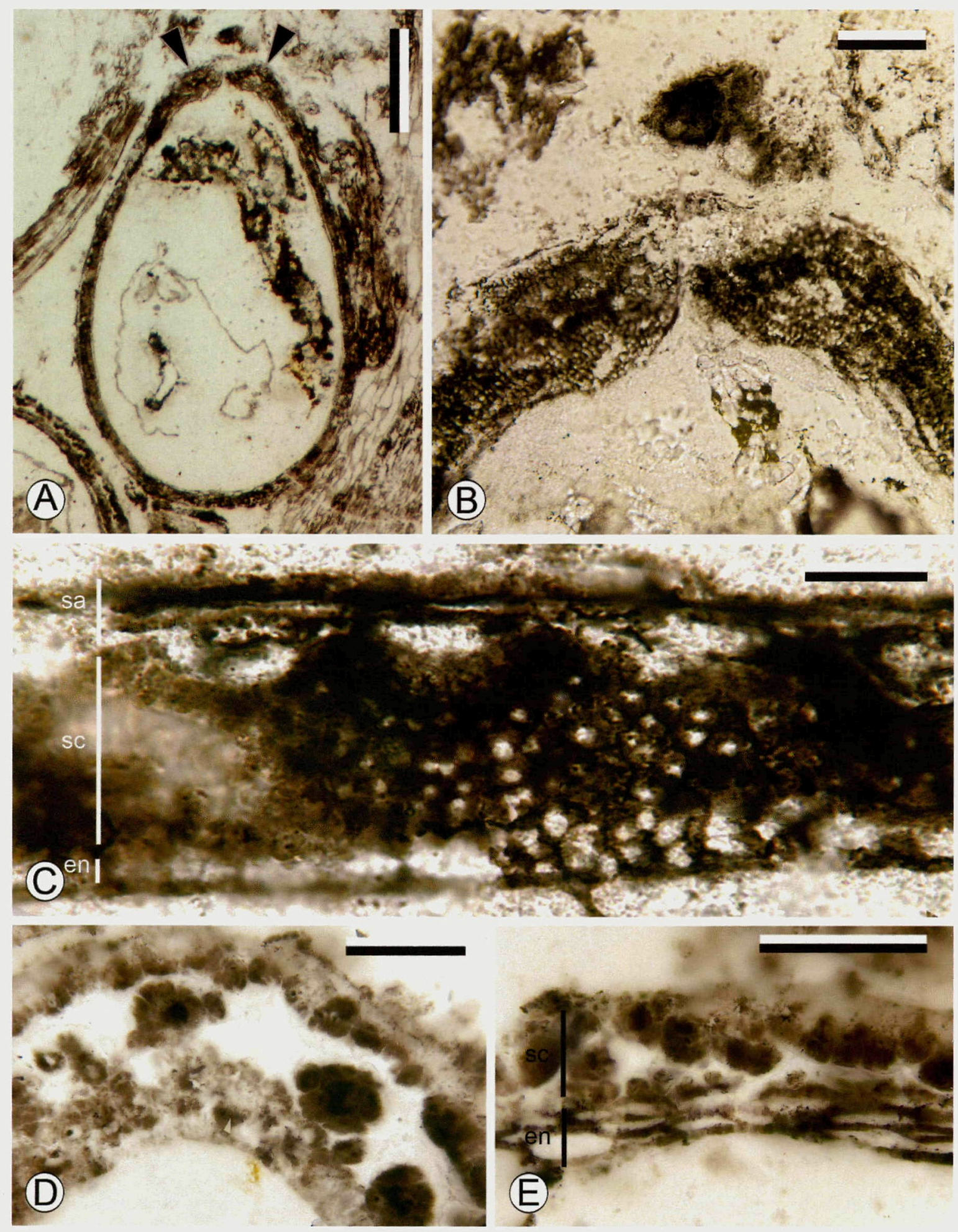

Fig. 3 Lonchiphyllum aplospermum holotype 15509 Cbot. A, Longitudinal section of an ovule illustrating the simple organization of the integument and the expansion of the sclerotesta around the micropyle (arrowheads). KU slide acquisition 26,625 (scale bar $=0.5 \mathrm{~mm}, 50 \times \mathrm{mag}$ ). $B$, Higher magnification of $A$ showing pitting on sclerotestal cell walls. KU slide acquisition 26,625 (scale bar $=0.25 \mathrm{~mm}, 200 \times$ mag). $C$, Longitudinal section of the integument showing the large cells of the sarcotesta (sa); the small, heavily sclerified cells of the sclerotesta (sc); and the position of the endotesta (en), which in this case is poorly preserved. KU slide acquisition 26,625 (scale bar $=25 \mu \mathrm{m}, 1000 \times$ mag). $D$, Cross section of part of the chalazal end of a seed showing circular clusters of sclereids in the sclerotesta, perhaps indicating the presence of tracheids within the integument. Interior of ovule is to the bottom. KU slide acquisition 26,683 (scale bar $=50 \mu \mathrm{m}, 630 \times$ mag). E, Cross section of part of the integument showing the sclerotesta (sc) and the fibrous endotesta (en). KU slide acquisition 26,683 (scale bar $=50 \mu \mathrm{m}, 630 \times \mathrm{mag}$.) 


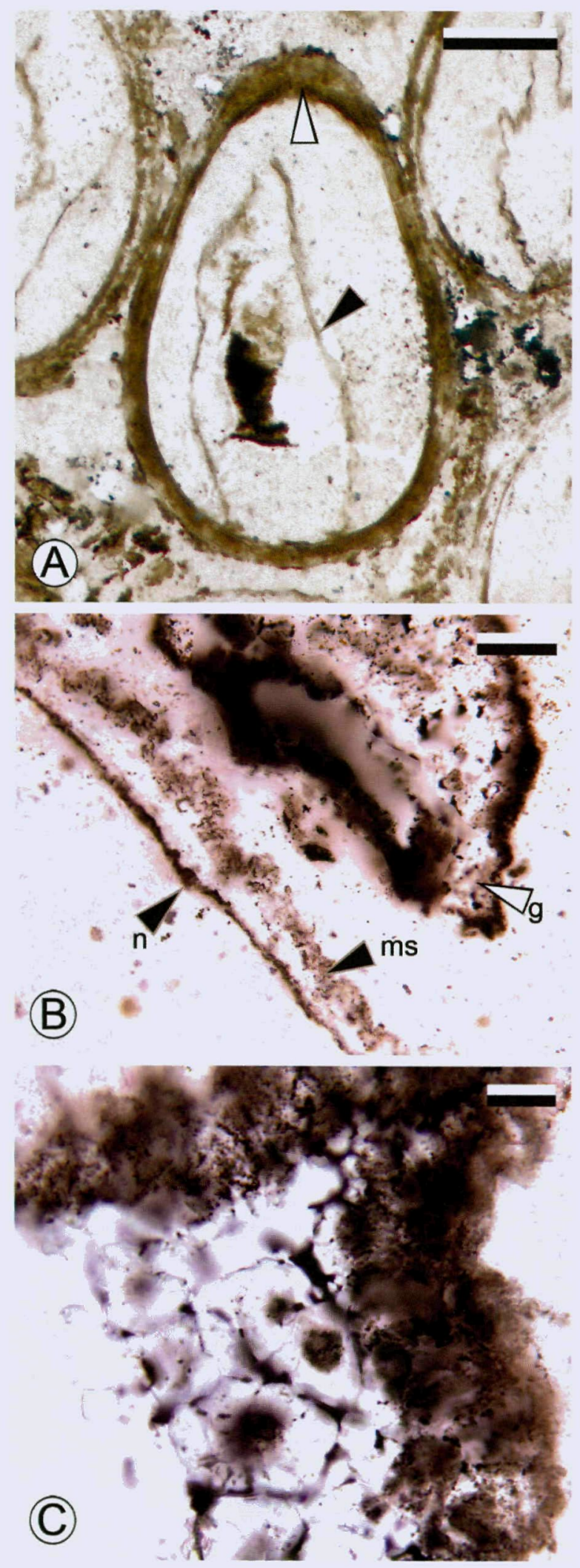

Fig. 4 Lonchiphyllum aplospermum holotype 15509 Cbot. A, Longitudinal section of an ovule illustrating the free nucellus (black arrowhead), thicker integument at the micropylar end (white arrowhead), and preserved gametophyte tissue. KU slide acquisition sclerotestal cells increase in size (fig. $3 A, 3 B$ ). The sclerotestal cells in this area have pitted thickenings on their walls (fig. $3 B)$. At the chalazal end of the ovule, clusters of thick-walled cells were observed and may indicate the presence of vascular bundles in the integument, at least at the chalazal end (fig. $3 D)$. There is no definitive line between the sarcotesta and the sclerotesta, and the inner walls of the sarcotesta are relatively thin and grade into the small thick-walled cells of the sclerotesta (fig. 3C). The same is true of the boundary between the sclerotesta and the endotesta.

Endotesta. Two to three cells make up the width of the endotesta. In longitudinal section, the endotesta is not always clear, and the sclerotesta appears to be adjacent to the ovule interior (fig. 3C). In transverse section, the cells are narrowly rectangular and appear as a crushed lining for the interior of the ovule (fig. $3 E$ ). The walls of the endotesta measure $3 \mu \mathrm{m}$ thick.

The nucellus is free from the integument and sinuous in outline (fig. $4 A$ [arrow], 4B). No specialized region appears to form near the micropyle, which indicates either that a simple pollen chamber was present or that detail is not preserved in the ovules. Cellular megagametophyte tissue is observed within the nucellus and megaspore membrane (fig. $4 \mathrm{C}$ ). No archegonia or embryos were observed in any of the ovules. In a few ovules, pollen present within the integument suggests that pollination had occurred by the time of preservation. The pollen is of the bisaccate Protohaploxypinus type.

\section{Discussion}

\section{Review of Ovules Described from Skaar Ridge}

Plectilospermum elliotii Taylor and Taylor 1987. The largest and most common ovule known from Skaar Ridge is Plectilospermum elliotii. It was illustrated but not described by Schopf $(1970,1976)$ and was the basis of an article on polyembryony (Smoot and Taylor 1986) before it was formally named and described (Taylor and Taylor 1987). The platyspermic ovules measure $4.8 \mathrm{~mm} \times 3.1 \mathrm{~mm}$ and are easily identifiable in the Skaar Ridge peat since they are so large (fig. $5 A$ ). The ovules have two sarcotestal wings, a two-layered sclerotesta, and an endotesta that is a single cell thick (fig. $5 B$ ). Within the sarcotestal wings is a parenchymatous region with large isodiametric cells surrounding the sclerotesta and extending into the wings. The sclerotesta is approximately six cells thick and contains highly sclerified isodiametric cells. The endotesta is fibrous with elongate rectangular cells. The nucellus is free from the integument, and megagametophyte tissue, archegonia, and embryos have been observed inside the ovules (fig. 5A, 5B; Smoot and Taylor 1986). None of the ovules has been found attached to a larger structure, and their anatomy led Schopf (1976) to assert that they were potentially cordaitalean. The absence of cordaitalean fossils in the peat does not

26,623 (scale bar $=0.25 \mathrm{~mm}, 100 \times \mathrm{mag}$ ). $B$, Cross section of an ovule showing nucellus (n), megasporangium (ms), and remains of gametophyte tissue (g). KU acquisition 26,644 (scale bar $=25 \mu \mathrm{m}$, $630 \times \mathrm{mag}) . \mathrm{C}$, Cross section of an ovule showing cellular gametophyte. KU slide acquisition 26,639 (scale bar $=10 \mu \mathrm{m}, 1000 \times$ mag). 


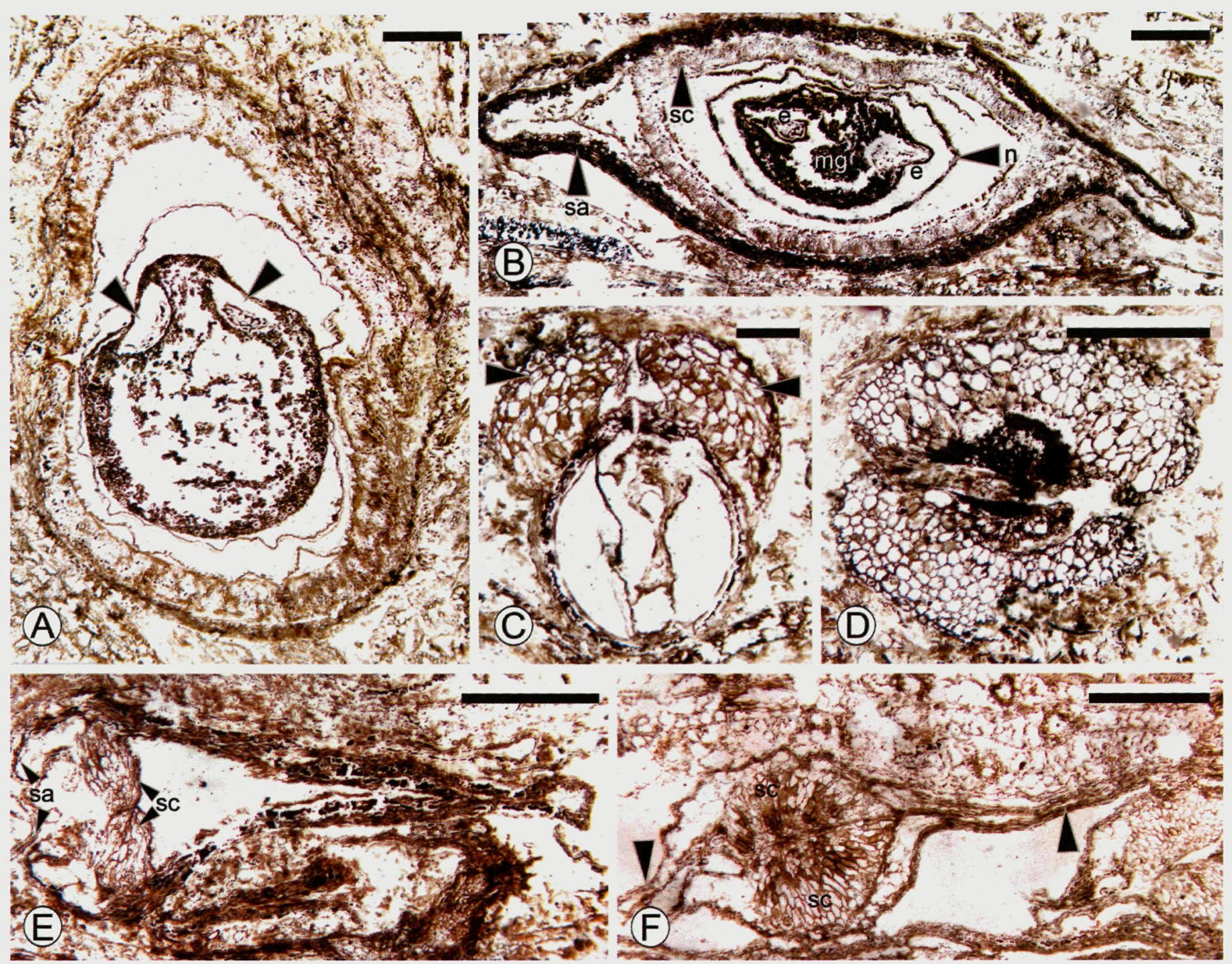

Fig. 5 Previously described ovules from the Skaar Ridge permineralized peat. A, Plectilospermum elliotii holotype ovule in longitudinal section with preserved gametophyte tissue and two archegonia (arrowheads) with the remains of embryos inside. KU slide acquisition 11,429 (scale bar $=$ $0.5 \mathrm{~mm}, 50 \times \mathrm{mag}$ ). B, P. elliotii paratype ovule in cross section showing sarcotestal wings (sa), sclerotesta layer (sc), free nucellus (n), preserved megagametophyte tissue (mg), and two developing embryos (e). KU slide acquisition 12,939 (scale bar = $0.5 \mathrm{~mm}, 50 \times \mathrm{mag}$ ). C, Choanostoma verruculosum paratype ovule in longitudinal section with sarcotestal parenchyma pads of tissue at the micropylar end (arrowheads). KU slide acquisition 15,476 (scale bar $=0.5 \mathrm{~mm}, 50 \times \mathrm{mag}$ ). D, Cross section of micropylar end of C. verruculosum paratype showing sarcotestal pads of tissue. KU slide acquisition 15,476 (scale bar $=0.5 \mathrm{~mm}, 50 \times \mathrm{mag}$ ). E, Longitudinal section of Lakkosia kerasata with sclerotestal pads of tissue (sc) and overarching sarcotestal tissue (sa). Micropylar end toward the left. KU slide acquisition 12,924 (scale bar $=0.5 \mathrm{~mm}, 50 \times \mathrm{mag}$ ). F, Cross section of $L$. kerasata with sclerotestal pads of tissue (sc) and sarcotestal wings (arrowheads). KU slide acquisition 26,393 (scale bar $=0.5 \mathrm{~mm}$, $50 \times \mathrm{mag})$.

support this hypothesis, and the abundance of Glossopteris leaves that surround the ovules provides stronger support for a glossopterid affinity. An ovule possibly attached to glossopterid vascular tissue has been observed, but incomplete preservation prevents confirmation. The lack of attachment of the hundreds of observed Plectilospermum ovules suggests that they may have been released from the parent plant before fossilization and the developing embryo relied on megagametophyte tissue for nutrition rather than receiving nutrients from the parent plant. Another hypothesis is that an event (e.g., a storm) could have caused the ovules to become disarticulated from the parent plant before they were ready for dispersal. Bioturbation is also present in all the peat specimens, owing to growth of Vertebraria roots through the leaf mats containing the ovules, and this may have disrupted the arrangement of any attached ovules.

Choanostoma verruculosum Klavins et al. 2001. The second isolated ovule known from this deposit, Choanostoma verruculosum (Klavins et al. 2001), is bilaterally symmetrical and measures $1.6-2.2 \mathrm{~mm} \times 1.5 \mathrm{~mm}$ (fig. $5 \mathrm{C}$ ). It is identified by large pads of sarcotestal tissue at the micropylar end of the ovule (fig. 5C, 5D). The sarcotesta forms these large pads of tissue, a small funnel-shaped region directly above the micropyle, and protuberances along the length of the ovule (fig. $5 \mathrm{C}$ ). The sclerotesta is composed of heavily sclerified cells, and the endotesta contains elongate rectangular cells. 
Megagametophyte tissue has been observed in Choanostoma, but archegonia and embryos are unknown.

Lakkosia kerasata Ryberg 2010. The third known ovule from Skaar Ridge is borne on the reproductive organ Lakkosia kerasata, and before Lonchiphyllum aplospermum it was the only known ovule attached to a sporophyll. Originally identified by Schopf and subsequent authors (Schopf 1976; Taylor and Taylor 1992), the ovules were formally described several years later (Ryberg 2010). The sporophyll has glossopterid venation similar to the leaves in the surrounding matrix, confirming a glossopterid affinity for these ovules. The ovule measures $3.5 \mathrm{~mm} \times 3.7 \mathrm{~mm}$ at its widest and has two sarcotestal wings and two large pads of sclerotestal tissue forming the micropyle (fig. $5 E, 5 F$ ). The location and testal layers that produce these pads, however, differ from those in Choanostoma (cf. fig. 5C, 5D and fig. 5E, 5F). Incomplete cellular preservation does not allow differentiation of layers of the integument near the chalaza. The nucellus is free from the integument, but poor preservation prevents the identification of gametophyte tissue along with archegonia or embryos.

\section{Glossopterid Ovule Diversity}

Although only two of the four described ovules from Skaar Ridge can definitively be associated with the glossopterids, the lack of material of other fossil seed plant groups does suggest that all of these ovules are most likely members of the Glossopteridales. If so, then at least four different types of glossopterid plants were present at this locality. With only two known leaves (Pigg 1990), one known root (Decombeix et al. 2009), and one microsporophyll (Ryberg et al. 2012a), the diversity of the ovules supports the hypothesis that the recognized diversity within the glossopterids is best defined by anatomically distinct megasporophyll/ovule genera. The size of the ovules ranges from up to $4.8 \mathrm{~mm}$ long in Plectilospermum to $1.1 \mathrm{~mm}$ in Lonchiphyllum. There are no regions of overlap in either the length or the width of the four ovulate genera. Lonchiphyllum is the smallest and simplest ovule found in the Skaar Ridge peat. It is easily found when clustered on a sporophyll since the presence of more than 100 ovules is hard to overlook in the peat. Integumentary features of Plectilospermum and Lonchiphyllum support their assignment to different genera (figs. $3 A, 5 A, 5 B$ ). The most recognizable difference is the presence of wings and a large parenchymatous sarcotesta in Plectilospermum (fig. 5B) as opposed to Lonchiphyllum, where the sarcotesta is only a single layer thick, with highly sclerified cells and potentially a thick outer cuticle (fig. 3C). The sclerotesta of the two genera are similar in having small, heavily sclerified cells, but this appears to be common among all the glossopterid ovules. The endotesta of these two genera are similar, but this also appears to be a common feature within Skaar Ridge glossopterid ovules. Beyond the great difference in size of the ovules, the morphology and anatomy of Plectilospermum and Lonchiphyllum differ enough to indicate that these were not produced by the same plant.

The parenchymatous pads of tissue at the micropylar end of Choanostoma and Lakkosia illustrate the morphological difference between these genera and Lonchiphyllum (figs. $3 A, 5 C, 5 E)$. The sclerotesta of all glossopterid ovule genera contain heavily sclerified cells, so this character does not provide anatomical evidence for differentiating them. Although similar in size $(1.1 \mathrm{~mm} \times 0.97 \mathrm{~mm}$ [Lonchiphyllum] vs. $2.2 \mathrm{~mm} \times 1.5 \mathrm{~mm}$ [Choanostoma]), lacking wings, and having similar sclerotestal and endotestal anatomy, in Choanostoma the large pads of tissue and the funnel formed by the sarcotesta illustrate the difference between these two genera (figs. $3 A, 5 C$ ). One thing that is interesting to note is the identical way in which the ovules seal off their micropyles (figs. 3B, 5C). The sclerotesta enlarges (three times as thick in Choanostoma and two times as thick in Lonchiphyllum) at the micropyle, producing cells with a larger diameter but the same wall thickness as the rest of the cells in the sclerotesta. The production of these larger cells apparently seals off the micropyle as the integument walls are pushed together. The largest difference between these two genera (the sarcotestal pads of tissue) does not appear to be due to differential preservation, as Lonchiphyllum ovules that are still attached to the sporophyll exhibit the same anatomy as those that are dispersed in the matrix. Out of the more than 100 ovules of Lonchiphyllum, not one showed any sort of ornamentation of the sarcotesta.

Interestingly, the two ovules with confirmed attachment to a sporophyll are the least alike morphologically. Lakkosia is highly ornamented at the micropylar region by both the sarcotesta and the sclerotesta (fig. $5 E$ ) and contains sarcotestal wings (fig. $5 F$ ). Lonchiphyllum contains no ornamentation or wings (fig. $3 A$ ). Both appear to be attached to a Glossopteris schopfii leaf because the anastomosing pattern and spherical shape of the vascular bundles (fig. $2 F$ ) in both genera are similar to those of G. schopfii. Lakkosia ovules are sunken into the adaxial surface (based on vascular bundle anatomy) of the sporophyll, while Lonchiphyllum ovules are only slightly sunken or not sunken at all into the adaxial surface of the sporophyll. The vascularization of the ovules is also different; in Lakkosia, a vascular bundle enters the base of the ovule and ends at the chalazal end of the ovule, whereas in Lonchiphyllum, the vasculature divides into numerous bundles and at least enters the basal portion of the sclerotesta. Because of incomplete preservation, it is not possible to see how far the vasculature extends through the integument.

Although Lonchiphyllum is different from other anatomically preserved ovules from Skaar Ridge, anatomically preserved ovules of Homevaleia gouldii are known from the Bowen Basin of Australia (Gould and Delevoryas 1977; Nishida et al. 2007). At first glance, Lonchiphyllum and Homevaleia appear similar; they have similarly sized ovules (1.1 $\mathrm{mm} \times 0.97 \mathrm{~mm}$ [Lonchiphyllum] vs. $1.3 \mathrm{~mm} \times 0.9 \mathrm{~mm}$ [Homevaleia]) and lack ornamentation of the sarcotesta or sclerotesta. Anatomical examination of the integuments, however, reveals differences between these genera. The sarcotesta of Homevaleia consists of thin-walled cells that form a network around the ovule, whereas in Lonchiphyllum the sarcotesta is a single cell layer of large sclerified cells. The sclerotesta in Homevaleia is vascularized and contains mucilage cells, features not seen in any of the Antarctic ovules.

\section{Pollination Modes}

The elaboration of the micropylar end of Lakkosia (fig. 5E) and Choanostoma (fig. 5C) may have been a method to aid 
in pollination. In Choanostoma, a small chamber is present between the base of these sarcotestal pads of tissue and the micropyle. In Lakkosia, a chamber is present between the overarching sarcotesta and the sclerotestal pads of tissue. These chambers may have allowed pollen grains to settle or become trapped near the micropyle instead of being blown away. These features may be derived features of glossopterid ovules to ensure pollination. In Lonchiphyllum sporophylls a large number of pollen grains are present surrounding the base of the ovules, suggesting that pollen fell en masse onto the sporophyll and landing on the micropyle of an ovule was by chance, as it is in many species of wind-pollinated gymnosperms. The micropyle of Plectilospermum is similar in its simplicity, but without known features of the sporophyll to which it was attached, specialized pollination features for the genus cannot be determined.

\section{Dispersal Methods}

The parenchymatous pads of tissue in Choanostoma and Lakkosia have been suggested as aids in seed dispersal (Klavins et al. 2001; Ryberg 2010). The ovules of Choanostoma have been observed only in a single peat block (13676) from Skaar Ridge, suggesting that the plant that bore these ovules was not as abundant as other taxa or perhaps they were dispersed further than other seeds. Klavins et al. (2001) suggested that the large parenchymatous pads at the micropylar end of the ovule in Choanostoma aided in dispersal by water, allowing the seeds to float along with the current. These masses of parenchyma tissue are absent in Plectilospermum, and there does not appear to be any tissue that may have aided in flotation, except perhaps for the parenchymatous tissue in the wings. If the suggestion of Klavins et al. (2001) is correct, then perhaps Plectilospermum seeds were deposited closer to the parent plant, whereas Choanostoma would have been deposited a greater distance away. The presence of both wings and the parenchymatous pads of tissue in
Lakkosia would suggest that these ovules would be able to disperse both locally (wings) and great distances (parenchyma pads). The potential of local dispersal is supported because this is the second-most prevalent seed genus in Skaar Ridge peat. Lonchiphyllum ovules have been found in only two peat blocks so far, but this may be due to the large number of ovules clustered together. The small size of the ovules, lack of ornamentation, and potential to be destroyed would make them difficult to discern as isolated ovules in peat specimens crowded with plant material.

\section{Conclusions}

This new genus of megasporophyll has confirmed the presence of at least two anatomically preserved glossopterid megasporophylls in the permineralized peat from Skaar Ridge, Antarctica. The different anatomy of these sporophylls and the presence of two more isolated ovules in the peat reveal greater floristic diversity not apparent from the abundant impressions of vegetative organs in Permian localities across Gondwana (Rigby and Schopf 1969; Rigby 1972; Cúneo 1996). Although Glossopteris leaves were the major component of Permian Antarctic floras (Cúneo et al. 1993), the range of glossopterid ovules provides a better picture of plant diversity. Although anatomically preserved plant fossils have been known from the Permian of Skaar Ridge for decades (Schopf 1970), new specimens are still being found and described. The potential of this deposit to reveal anatomical information on the Glossopteridales has yet to be exhausted.

\section{Acknowledgment}

This article is dedicated to Thomas N. Taylor in his seventyfifth year: a wonderful teacher, mentor, and friend.

\section{Literature Cited}

Banerjee M 1984 Fertile organs of the Glossopteris flora and their possible relationships in the line of evolution. Pages 29-59 in AK Sharma, GC Mitra, M Banerjee, eds. Proceedings of the Symposium on Evolutionary Botany and Biostratigraphy. Today \& Tomorrow, New Delhi.

Barrett PJ, DH Elliot, JF Lindsay 1986 The Beacon Supergroup (Devonian-Triassic) and Ferrar Group (Jurassic) in the Beardmore Glacier area, Antarctica. Pages 339-428 in MD Turner, JD Splettstoesser, eds. Geology of the central Transantarctic Mountains. Antarctic Research Series 36. American Geophysical Union, Washington, DC.

Collinson JW 1991 The palaeo-Pacific margin as seen from East Antarctica. Pages 199-204 in MRA Thomson, JA Crame, JW Thomson, eds. Geological evolution of Antarctica. Cambridge University Press, Cambridge.

Cúneo NR 1996 Permian phytogeography in Gondwana. Palaeogeogr Palaeoclimatol Palaeoecol 125:75-104.

Cúneo NR, J Isbell, EL Taylor, TN Taylor 1993 The Glossopteris flora from Antarctica: taphonomy and paleoecology. Pages 13-40 in S Archangelsky, ed. Comptes Rendus Douzième Congrès International de Géologie du Carbonifère et Permien, Buenos Aires. Vol 2. Nanjing University Press, Nanjing.
Decombeix AL, EL Taylor, TN Taylor 2009 Secondary growth in Vertebraria roots from the Late Permian of Antarctica: a change in developmental timing. Int J Plant Sci 170:644-656.

Farabee MJ, EL Taylor, TN Taylor 1991 Late Permian palynomorphs from the Buckley Formation in the central Transantarctic Mountains. Rev Palaeobot Palynol 69:353-368.

Galtier JM, TL Phillips 1999 The acetate peel technique. Pages 6770 in TP Jones, N Rowe, eds. Fossil plants and spores: modern techniques. Geological Society of London, London.

Galtier JM, TN Taylor 1994 The first record of ferns from the Permian of Antarctica. Rev Palaeobot Palynol 83:227-239.

Gould RE, T Delevoryas 1977 The biology of Glossopteris: evidence from petrified seed-bearing and pollen-bearing organs. Alcheringa 1:387-399.

Gulbranson EL, JL Isbell, EL Taylor, PE Ryberg, TN Taylor, PP Flaig 2012 Permian polar forests: deciduousness and environmental variation. Geobiology 10:479-495.

Isbell JL 1991 Evidence for a low-gradient alluvial fan from the palaeo-Pacific margin in the Upper Permian Buckley Formation, Beardmore Glacier area, Antarctica. Pages 215-217 in MRA Thomson, JA Crame, JW Thomson, eds. Geological evolution of Antarctica. Cambridge University Press, Cambridge. 
Joy KW, AJ Willis, WS Lacey 1956 A rapid cellulose peel technique in palaeobotany. Ann Bot 20:635-637.

Klavins SD, EL Taylor, M Krings, TN Taylor 2001 An unusual, structurally preserved ovule from the Permian of Antarctica. Rev Palaeobot Palynol 115:107-117.

Lindström S, S McLoughlin, AN Drinnan 1997 Intraspecific variation of taeniate bisaccate pollen within Permian glossopterid sporangia, from the Prince Charles Mountains, Antarctica. Int J Plant Sci 158: 673-684.

McLoughlin S, AN Drinnan 1996 Anatomically preserved Permian Noeggerathiopsis leaves from East Antarctica. Rev Palaeobot Palynol 92:207-227.

Nishida H, KB Pigg, K Kudo, JF Rigby 2004 Zooidogamy in the Late Permian genus Glossopteris. J Plant Res 117:323-328.

2007 New evidence of reproductive organs of Glossopteris based on permineralized fossils from Queensland, Australia. I. Ovulate organ Homevaleia gen. nov. J Plant Res 120:539-549.

Pigg KB 1990 Anatomically preserved Glossopteris foliage from the central Transantarctic Mountains. Rev Palaeobot Palynol 66:105-127.

Pigg KB, S McLoughlin 1997 Anatomically preserved Glossopteris leaves from the Bowen and Sydney basins, Australia. Rev Palaeobot Palynol 97:339-359.

Pigg KB, TN Taylor 1993 Anatomically preserved Glossopteris stems with attached leaves from the central Transantarctic Mountains, Antarctica. Am J Bot 80:500-516.

Rasband WS 1997-2008 Image J. National Institutes of Health, Bethesda, MD. http://rsb.info.nih.gov/ij/.
Rigby JF 1972 The flora of the Kaloola Member of the Baralaba Coal Measures, central Queensland. Publ Geol Surv Qld 352:1-15.

Rigby JF, JM Schopf 1969 Stratigraphic implications of Antarctic paleobotanical studies. Pages 91-106 in AJ Amos, ed. Gondwana stratigraphy. UNESCO, Paris.

Ryberg PE 2009 Reproductive diversity of Antarctic glossopterid seed-ferns. Rev Palaeobot Palynol 158:167-179.

— 2010 Lakkosia kerasata gen. et sp. nov., a permineralized megasporangiate glossopterid structure from the central Transantarctic Mountains, Antarctica. Int J Plant Sci 171:332-344.

Ryberg PE, EL Taylor, TN Taylor 2012a The first permineralized microsporophyll of the Glossopteridales: Eretmonia macloughlinii sp. nov. Int J Plant Sci 173:812-822.

$2012 b$ Permineralized lycopsid from the Permian of Antarctica. Rev Palaeobot Palynol 169:1-6.

Schopf JM 1970 Petrified peat from a Permian coal bed in Antarctica. Science 169:274-277.

1976 Morphologic interpretation of fertile structures in glossopterid gymnosperms. Rev Palaeobot Palynol 21:25-64.

Smoot EL, TN Taylor 1986 Evidence of simple polyembryony in Permian seeds from Antarctica. Am J Bot 73:1079-1081.

Taylor EL, TN Taylor 1992 Reproductive biology of the Permian Glossopteridales and their suggested relationship to flowering plants. Proc Natl Acad Sci USA 89:11495-11497.

Taylor TN, EL Taylor 1987 Structurally preserved fossil plants from Antarctica. III. Permian seeds. Am J Bot 74:904-913. 